\title{
Renal pseudohypoaldosteronism type 1
}

INSERM

\section{Source}

INSERM. (1999). Orphanet: an online rare disease and orphan drug data base. Renal pseudohypoaldosteronism type 1. ORPHA:171871

Renal pseudohypoaldosteronism type 1 (renal PHA1) is a mild form of primary mineralocorticoid resistance restricted to the kidney. 